\title{
XXXIV. angiologické dny s mezinárodní účastí
}

Ve dnech 26.-28. 2. 2009 se konaly v kongresových sálech hotelu Diplomat v Praze tradiční XXXIV. angiologické dny. $\mathrm{V}$ tomto roce bylo registrováno více než 400 účastníků, $\mathrm{z}$ toho 69 zahraničních hostů. Program probíhal paralelně ve třech sálech, některé bloky byly věnovány sesterské problematice. Velkým obohacením odborného programu byl blok amerických řečníků z Mayo Clinic v Rochesteru.

$\mathrm{V}$ rámci kongresu bylo uděleno čestné členství doc. M. Bulvasovi a dr. Z. Kasalové za celoživotní prrínos angiologii. Proběhly soutěže o nejlepší publikované původní práce, z nichž Prusíkovu cenu získal dr. M. Chochola z 2. interní kliniky 1 . LF UK v Praze za publikaci věnovanou problematice kmenových buněk u kritické končetinové ischemie, dr. V. Tuka z 3. interní kliniky stejné fakulty získal Reinišovu cenu za sledování parametrů toku $\mathrm{v}$ arterio-venózních shuntech u dialyzovaných nemocných. Jako nejlepší monografie roku 2008 byla oceněna kniha prof. J. Mazucha ze Slovenska. Ocenění za nejlepší práci s žilní problematikou získal dr. R. Malý z Hradce Králové za hodnocení výskytu žilní trombózy u psychiatrických pacientů a vyhodnocení vlivů specifické terapie na vznik trombózy.

Rok po úmrtí doc. V. Puchmayera, prvního předsedy samostatně konstituované České angiologické společnosti, proslovil pamětní př̀ednášku doc. J. Linhart, DrSc., který shrnul vývoj angiologie jako oboru v IKEM od 60. let minulého století.

Velmi zdařilý byl blok pracovní skupiny pro intervenční angiologii, který byl věnován problematice endovaskulární léčby aneurysmat abdominální aorty. Probíhal prrímý přenos z katetrizačního sálu na 2. interní klinice kardiologie a angiologie VFN v Praze, kde tým intervenčních angiologů (dr. P. Vařejka, dr. S. Heller), spolu s chirurgem a anesteziologem implantovali do břišní aorty stentgraft Aorfix a vysvětlovali strategii výkonu a jeho úskalí. I zahraniční účastníci oceňovali technickou kvalitu přenosu a zejména vlastní um lékařủ, kteří výkon prováděli.

$\mathrm{V}$ sekci věnované tromboembolické nemoci diskutovali autoři (prof. J. Widimský sen. a prof. J. Malý) o nových českých doporučeních pro prevenci a léčbu plicní embolie.

V samostatném bloku byly představeny pilotní výsledky projektu MOET ICHDK (monitorování účinné terapie ICHDK), do kterého je v současné době zapojeno 300 praktických lékařù, kteří v rámci cíle projektu (časná detekce a optimalizace léčby periferní tepenné aterosklerózy) sledují 3500 nemocných $s$ danou diagnózou.

Angiologové z Mayo Clinic připravili pestrý blok s přednáškami s žilní problematikou, kde zaujal pohled na neinvazivní sledování žilní hemodynamiky a léčbu varikozity. Vedoucí angiologické skupiny dr. R. Shields shrnul přehled léčebné strategie u plicní embolie, kde trombolytická léčba je podávána jen u embolizací zásadně hemodynamicky destabilizujících; ve srovnání s Evropou a zvyklostem v naší republice je antikoagulační léčba u ostatních nemocných dosud prováděna nefrakcionovaným heparinem. Zajímavá byla prezentace rekanalizace dolní duté žíly pomocí perkutánního stentingu cestou kaválního filtru u chronických okluzí dolní duté žíly a ilických žil.

Stěžejní přednášku o vývoji rizikových faktorů kardiovaskulárních onemocnění v České republice $\mathrm{v}$ průběhu posledních více než dvaceti let přednesla prof. R. Cífková z IKEM. Konstatovala, že u nás klesá celková i kardiovaskulární mortalita díky nižší úmrtnosti na cévní mozkové př́hody a ischemickou chorobu srdeční. Př́źnivý trend je v poklesu prevalence arteriální hypertenze u žen, přičemž se celkově zlepšuje kontrola hypertenze u léčených; stejně tak příznivě klesá průměrná hodnota celkového cholesterolu a stoupá počet léčených pro dyslipidemii. U mužů klesl počet kuřáků o třetinu, stoupá však jejich BMI.

Další samostatné bloky pokrývaly tematiku perkutánních intervencí v léčbě stenóz karotického řečiště a nových možností rekanalizace periferních tepen (subintimální rekanalizace, použití aterektomů), sekce kritické končetinové ischemie řešila výsledky aplikace autologních kmenových buněk, vícenásobnou sekvenční revaskularizaci pedálními bypassy, metodu rheoferézy.

Praktické byly workshopy týkající se role duplexní sonografie při vyšetření abdominální aorty, antikoagulační léčby a jejího monitorování pomocí CoaguCheku (s prezentací zkušeností angiologickými sestrami); ambulantní angiologové sestavili blok s tématem diferenciální diagnostika bolesti v končetině za účasti ortopeda a neurologa.

V bloku České společnosti pro trombózu a hemostázu byla prezentována řada přednášek, přičemž práce dr. Z. Kudrnové z Trombotického centra VFN, řešící prííčiny žilního tromboembolismu, byla oceněna jako nejlepší prezentace autora do 35 let věku. Nejlepší sesterskou přednáškou byla vyhodnocena „Cestovní trombóza“, přednesená sestrou M. Malou z 2. interní kliniky kardiologie a angiologie VFN v Praze.

Kongres měl tradičně i zdařilý doprovodný program. Domácí i zahraniční účastníci mohli vést neformální diskuse při pohledu na impozantní panoráma Hradčan z kavárny Slavia.

Doc. MUDr. Debora Karetová, CSc., 2. interní klinika kardiologie a angiologie, VFN a 1. LF UK, Praha, e-mail: dkare@lf1.cuni.cz 